\title{
Activation of Muscarinic Acetylcholine Receptors Enhances the Release of Endogenous Cannabinoids in the Hippocampus
}

\author{
Jimok Kim, ${ }^{1,2}$ Masako Isokawa, ${ }^{1,2}$ Catherine Ledent, ${ }^{3}$ and Bradley E. Alger ${ }^{1,2}$ \\ ${ }^{1}$ Program in Neuroscience and ${ }^{2}$ Department of Physiology, University of Maryland School of Medicine, Baltimore, \\ Maryland 21201, and 3/nstitut de Recherche Interdisciplinaire en Biologie Humaine et Nucléaire, Université Libre de \\ Bruxelles, B-1070 Brussels, Belgium
}

Endogenous cannabinoids (endocannabinoids) are endogenous compounds that resemble the active ingredient of marijuana and activate the cannabinoid receptor in the brain. They mediate retrograde signaling from principal cells to both inhibitory ["depolarization-induced suppression of inhibition" (DSI)] and excitatory ("depolarization-induced suppression of excitation") afferent fibers. Transient endocannabinoid release is triggered by voltage-dependent $\mathrm{Ca}^{2+}$ influx and is upregulated by group I metabotropic glutamate receptor activation. Here we show that muscarinic acetylcholine receptor (mAChR) activation also enhances transient endocannabinoid release (DSI) and induces persistent release. Inhibitory synapses in the rat hippocampal CA1 region of acute slices were studied using wholecell patch-clamp techniques. We found that low concentrations (0.2-0.5 $\mu \mathrm{M})$ of carbachol (CCh) enhanced DSI without affecting

Activation of muscarinic acetylcholine receptors (mAChRs) affects individual neurons by influencing several types of ionic currents: the M-current (Adams et al., 1982; Halliwell and Adams, 1982), the $\mathrm{K}^{+}$"leak" current (Madison et al., 1987), the slow $\mathrm{Ca}^{2+}$-activated $\mathrm{K}^{+}$current (Cole and Nicoll, 1984), the $\mathrm{Ca}^{2+}$ activated nonselective cation current (Guérineau et al., 1995; Fraser and MacVicar, 1996), and voltage-dependent $\mathrm{Ca}^{2+}$ current (Beech et al., 1991; Howe and Surmeier, 1995; Yan and Surmeier, 1996; Shapiro et al., 1999). Muscarinic agonists also influence the firing behavior of neuronal populations by activating different mAChR subtypes on different classes of cells. For instance, " $\theta$ rhythms" (Fischer et al., 1999; Buzsaki, 2002) and " $\gamma$ rhythms" (Fisahn et al., 1998) are initiated by mAChR agonists. Stimulation of cholinergic afferents activates a population of GABAergic interneurons (Pitler and Alger, 1992a; Behrends and ten Bruggencate, 1993), and the cholinergic induction of $\gamma$ rhythms depends in large part on the activation of GABAergic interneurons (Fisahn et al., 1998, 2002).

The diverse phenomena caused by $\mathrm{mAChR}$ activation are generally thought to result directly from modulation of ionic currents. However, the existence of endogenous cannabinoids

\footnotetext{
Received April 22, 2002; revised Sept. 19, 2002; accepted Sept. 24, 2002.

The work was supported by United States Public Health Service Grants RO1 DA14725 and RO1 NS30219 (B.E.A.) J.K. was supported by the Training Program in Neuroscience T32 DE1474. Most of this work is contained in the PhD thesis of J.K. We thank Scott Thompson and Darrin Brager for their comments on a draft of this manuscript.

Correspondence should be addressed to Dr. Bradley E. Alger, Department of Physiology, University of Maryland School of Medicine, 655 West Baltimore Street, Baltimore, MD 21201. E-mail: balger@umaryland.edu.

Copyright (C) 2002 Society for Neuroscience 0270-6474/02/2210182-10\$15.00/0
}

basal evoked IPSCs (elPSCs) by activating mAChRs on postsynaptic cells. Higher concentrations of CCh $(\geq 1 \mu \mathrm{M})$ enhanced DSI and also persistently depressed basal elPSCs, mainly by releasing endocannabinoids. Persistent CChinduced endocannabinoid release did not require an increase in $\left[\mathrm{Ca}^{2+}\right]_{\mathrm{i}}$ but was dependent on $\mathrm{G}$-proteins. Although they were independent at the receptor level, muscarinic and glutamatergic mechanisms of endocannabinoid release shared intracellular machinery. Replication of the effects of CCh by blocking acetylcholinesterase with eserine suggests that mAChRmediated endocannabinoid release is physiologically relevant. This study reveals a new role of the muscarinic cholinergic system in mammalian brain.

Key words: GABAergic IPSC; mAChR; DSI; retrograde messenger; retrograde signaling; $m$ GluR (endocannabinoids) (Di Marzo et al., 1998; Piomelli et al., 2000), lipid-derived messengers that resemble the psychoactive ingredient in marijuana (Ameri, 1999), and retrograde signaling systems that use endocannabinoids (Ohno-Shosaku et al., 2001; Wilson and Nicoll, 2001) raises other possibilities. Normally, increases in $\left[\mathrm{Ca}^{2+}\right]_{\mathrm{i}}$ in the principal cells (Llano et al., 1991; Pitler and Alger, 1992b; Ohno-Shosaku et al., 1998; Lenz and Alger, 1999) lead to the induction of "depolarization-induced suppression of inhibition" (DSI) (Alger and Pitler, 1995), which is caused by the release of endocannabinoids (Ohno-Shosaku et al., 2001; Wilson and Nicoll, 2001) that selectively bind to and activate CB1-type cannabinoid receptors (CB1Rs). CB1Rs are selectively localized on the nerve terminals of a subset of GABAergic interneurons (Tsou et al., 1998; Katona et al., 1999), and CB1R activation causes a decrease in GABA release from the cells probably by reducing N-type $\mathrm{Ca}^{2+}$ current (Hoffman and Lupica, 2000; Wilson et al., 2001). Recent reports show that the activation of group I metabotropic glutamate receptors (mGluRs) can release endocannabinoids in the cerebellum (Maejima et al., 2001) and hippocampus (Varma et al., 2001; Ohno-Shosaku et al., 2002). In the hippocampus, low concentrations of mGluR agonists also enhance DSI without suppressing evoked IPSC (eIPSC) amplitudes, which suggests an interaction between mGluRs and $\mathrm{Ca}^{2+}$-dependent endocannabinoid release (Varma et al., 2001; Ohno-Shosaku et al., 2002).

mAChR agonists have two opposing effects on IPSCs (Pitler and Alger, 1992a; Behrends and ten Bruggencate, 1993): they depress eIPSCs and enhance spontaneous IPSC (sIPSC) activity. Not all interneurons are susceptible to DSI (Martin and Alger, 1999; Wilson et al., 2001) because they do not all possess CB1Rs 
(Tsou et al., 1998; Katona et al., 1999). mAChR activation enhances DSI of sIPSCs in part by selectively stimulating interneurons that are DSI susceptible (Martin and Alger, 1999; Martin et al., 2001). However, eIPSCs also undergo DSI, and DSI of eIPSCs is also very robust in the presence of an mAChR agonist. Hence, activation of susceptible interneurons is probably not the sole mechanism of DSI enhancement by mAChRs (Lenz and Alger, 1999). The depression of eIPSCs and the enhancement of DSI could be caused by direct modulation of ionic currents of interneurons. Alternatively, both effects could reflect increased endocannabinoid release.

In this study, we show that $\mathrm{mAChR}$ activation can enhance endocannabinoid release independently of the mGluR system. This is a new role of the cholinergic system in the brain and will broaden our understanding of interactions between neurotransmitter systems. Our results also show some similarities between the mAChR and mGluR systems. Endocannabinoids play diverse roles in retrograde signaling, neuroprotection (van der Stelt et al., 2001; Panikashvili et al., 2002), and analgesia (Calignano et al., 1998; Ameri, 1999). GABA reduction by endocannabinoid may be important in long-term potentiation induction (Carlson et al., 2002). Our study contributes to building a connection from the cholinergic system to these endocannabinoidmediated phenomena.

\section{MATERIALS AND METHODS}

Preparation of slices. Hippocampal slices were obtained mainly from 4- to 6-week-old male Sprague Dawley rats. In some experiments, as noted, mice $(25-40 \mathrm{gm})$ in which the gene for CB1R had been invalidated (Ledent et al., 1999) were used. All experiments were performed in accordance with the guidelines set forth by the Institutional Animal Care and Use Committee of the University of Maryland School of Medicine. After the animals were deeply anesthetized with halothane and decapitated, the hippocampi were removed and sectioned into 400- $\mu$ m-thick slices in ice-cold saline using a Vibratome (Technical Products International, St. Louis, MO). The slices were maintained at room temperature in an interface holding chamber in a humidified atmosphere saturated with $95 \% \mathrm{O}_{2} / 5 \% \mathrm{CO}_{2}$. The slices were used $\geq 1 \mathrm{hr}$ after sectioning. The recording chamber warmed the submerged slice, and experiments were performed at $30 \pm 1{ }^{\circ} \mathrm{C}$ (Nicoll and Alger, 1981).

Electrophysiology. Whole-cell voltage-clamp recordings of CA1 pyramidal cells were done using the "blind" patch method (Blanton et al., 1989). Electrode resistances in the bath were 3-6 $\mathrm{M} \Omega$, and recordings with series resistance $<35 \mathrm{M} \Omega$ were accepted. During experiments, series resistance was checked by $-1 \mathrm{mV}$ hyperpolarizing voltage steps, and data associated with obvious changes of series resistance or unstable current baseline were discarded. The holding potential was $-70 \mathrm{mV}$ in all experiments. Monosynaptic eIPSCs were elicited by $100 \mu \mathrm{sec}$ extracellular stimuli delivered with concentric bipolar stimulating electrodes (David Kopf Instruments, Tujunga, CA) placed in stratum oriens between CA3 and CA1, 0.5-1 mm apart from the recording site. Data were collected using an Axopatch 1C amplifier (Axon Instruments, Union City, CA), filtered at $2 \mathrm{kHz}$, and digitized at $5 \mathrm{kHz}$ using a Digidata 1200 and Clampex 8 software (Axon Instruments).

The intracellular recording solution contained (in mM): $90 \mathrm{CsCH}_{3} \mathrm{SO}_{3}$, $50 \mathrm{CsCl}, 1 \mathrm{MgCl}_{2}, 2 \mathrm{Mg}$-ATP, 0.3 Tris-GTP, $0.2 \mathrm{Cs}_{4}$-BAPTA, 10 HEPES, and 5 QX-314 (pH 7.2 with $\mathrm{CsOH}$ and $295 \mathrm{mOsm})$. In some experiments (see Fig. 6), $0.3 \mathrm{~mm}$ Tris-GTP was replaced by $1 \mathrm{~mm}$ GTP $\gamma \mathrm{S}-\mathrm{Li}_{4}$ to block further activation of G-proteins, or $90 \mathrm{~mm}$ $\mathrm{CsCH}_{3} \mathrm{SO}_{3}$ was replaced by $35 \mathrm{mM} \mathrm{Cs}_{4}$-BAPTA (Molecular Probes, Eugene, OR) to block a rise in $\left[\mathrm{Ca}^{2+}\right]_{\mathrm{i}}$. The extracellular solution included (in mM): $120 \mathrm{NaCl}, 3 \mathrm{KCl}, 25 \mathrm{NaHCO}_{3}, 1 \mathrm{NaH}_{2} \mathrm{PO}_{4}, 2.5 \mathrm{CaCl}_{2}$, $2 \mathrm{MgSO}_{4}$, and 15 glucose (300 mOsm). The extracellular solution was oxygenated with $95 \% \mathrm{O}_{2} / 5 \% \mathrm{CO}_{2}$ gas and flowed continuously through the recording chamber at a rate of $\sim 1 \mathrm{ml} / \mathrm{min}$.

To isolate monosynaptic eIPSCs, ionotropic glutamate receptor blockers $10 \mu \mathrm{M}$ 1,2,3,4-tetrahydro-6-nitro-2,3-dioxo-benzo[f]quinoxaline-7sulfonamide and $50 \mu \mathrm{M}$ dl-2-amino-5-phosphonopentanoic acid were present in the bath solution throughout the experiments. For the experiments in Figures 3 and 7, slices were preincubated with $4 \mu \mathrm{M}$ AM251 for
2-5 hr, except for four cells in Figure $3 A a$, which were treated with AM251 from the onset of the whole-cell configuration, i.e., for $>20 \mathrm{~min}$. Water-based stock solutions of carbachol (CCh), trans-[1S,3R]-1-amino1,3-cyclopentanedicarboxylic acid (ACPD), atropine, LY341495 (Tocris, Ballwin, MO), or DMSO-based stock solutions of AM251 (Tocris) and $(R)$-(+)-[2,3-dihydro-5-methyl-3-(4-morpholinylmethyl)pyrrolo-[1,2,3-de]1,4-benzoxazin-6-yl]-1-naphthalenylmethanone mesylate (W IN 55212-2) (Tocris) were added to the bath solution and perfused into the recording chamber when needed. The final concentration of DMSO was $0.01 \%(\mathrm{v} / \mathrm{v})$. All other chemicals were purchased from Sigma (St. Louis, MO).

$\mathrm{Ca}^{2+}$ imaging. For imaging pyramidal cell $\left[\mathrm{Ca}^{2+}\right]_{\mathrm{i}}, 100 \mu \mathrm{M}$ Fluo3 plus $0.1 \mathrm{~mm}$ EGTA was included in the recording pipette solution in place of $0.2 \mathrm{~mm} \mathrm{Cs}_{4}$-BAPTA. After a whole-cell recording was established, the cell was held at $-70 \mathrm{mV}$ for $10 \mathrm{~min}$ before imaging to establish diff usion equilibrium of the dye. The dye was excited with a $480 \mathrm{~nm}$ wavelength light provided by filtering the output from a $100 \mathrm{~W}$ mercury bulb. Images were collected by a cooled CCD camera (Roper, Tucson, AZ) and analyzed by IPLab software (Scanalytics, Fairfax, VA). For each trial, eight baseline fluorescence images were acquired immediately before a DSI-inducing depolarization step was delivered. $\Delta F / F$ was calculated for a total of 100 images that were acquired sequentially every $130 \mathrm{msec}$, where $F$ is the fluorescence intensity when the cell is at rest, and $\Delta F$ is the change in fluorescence during activity.

Data analysis. We evoked IPSCs at $4 \mathrm{sec}$ intervals and depolarized the postsynaptic cell to $0 \mathrm{mV}$ for $1 \mathrm{sec}$ at $88 \mathrm{sec}$ intervals. The mean amplitude of five eIPSCs just before the depolarization pulse was taken as the control amplitude, and the mean of four eIPSCs just after the pulse was taken as the eIPSC amplitude during the DSI period. The magnitude of DSI of eIPSCs was calculated by taking the ratio of these two mean amplitudes, i.e., DSI $(\%)=(1-$ mean of four eIPSCs after depolarizing pulse/mean of five eIPSCs before depolarizing pulse) $\times$ 100 .

A DSI value of $0 \%$ means no reduction of eIPSC, and a value of $100 \%$ means complete reduction. Values of three DSI trials were averaged to obtain a mean DSI in a given condition. In some experiments, we also studied DSI of sIPSCs. To calculate DSI of sIPSCs, we integrated the sIPSC waveforms for $20 \mathrm{sec}$ before the depolarization pulse and $16 \mathrm{sec}$ after the pulse. Before integration, we adjusted the baseline of the current waveform to 0 . We took the ratio of the integrations (charge) after dividing them by time, i.e., DSI $(\%)=[1-$ (charge through sIPSC for $16 \mathrm{sec}$ after pulse/16 sec)/(charge through sIPSC for $20 \mathrm{sec}$ before pulse $/ 20 \mathrm{sec}) \times 100]$. To quantify a change in DSI, we simply subtracted two values of DSI, i.e., $\Delta$ DSI = experimental DSI - control DSI.

Data analysis was done in Clampfit 8 (Axon Instruments), and graphs were drawn in SigmaPlot 2000 [Statistical Program for the Social Sciences (SPSS), Chicago, IL]. $t$ tests were done in Excel XP (Microsoft Corporation, Redmund, WA), and ANOVA was done in Systat 10 (SPSS). All $t$ tests were two-tailed tests, and the $p$ value for significance was $<0.05$. For multiple comparisons, we used ANOVA (or repeated measures ANOVA, where appropriate), and only when $p<0.05$ did we perform $t$ tests (or paired $t$ tests).

\section{RESULTS}

High concentrations $(\geq 1 \mu \mathrm{M})$ of the mAChR agonist, $\mathrm{CCh}$, enhance DSI of sIPSCs indirectly by markedly enhancing the activity of the interneurons that are susceptible to DSI (Martin et al., 2001), but we wanted to determine whether mAChR activation could promote DSI process directly. Because DSI of sIPSCs changes with the number of DSI-sensitive interneurons that are active, we cannot determine the changes in the DSI process itself if the number of interneurons is changed. To circumvent this difficulty, we measured DSI of eIPSCs because the eIPSC is generated from the same number of interneurons before and after CCh application. At low concentrations $(0.2$ or $0.5 \mu \mathrm{M}), \mathrm{CCh}$ enhanced DSI of eIPSC significantly (paired $t$ test; $p<0.01$ ) (Fig. $1 A, B, E$ ) without affecting eIPSC amplitudes (paired $t$ test, $p>$ $0.1)($ Fig. $1 F)$. The increase in DSI $(\Delta \mathrm{DSI})$ was $16 \pm 4 \%(n=7)$ in $0.2 \mu \mathrm{M} \mathrm{CCh}$ and $27 \pm 5 \%(n=7)$ in $0.5 \mu \mathrm{M}$ (Fig. $1 E)$. Note that, from the equation (see Materials and Methods), $\Delta$ DSI represents an absolute increase in \%DSI, not a fractional increase 

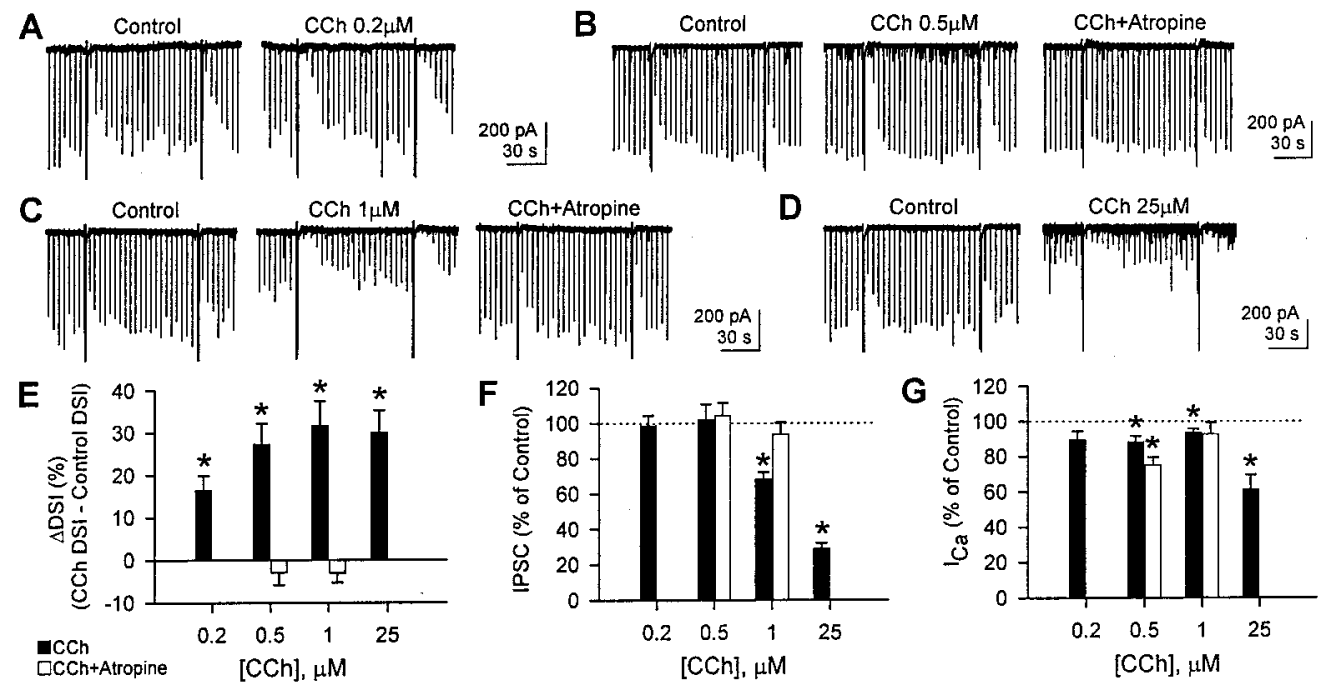

Figure 1. CCh enhances DSI and depresses eIPSC amplitudes. eIPSCs were evoked every $4 \mathrm{sec}$, and cells were depolarized to $0 \mathrm{mV}$ from the holding potential of $-70 \mathrm{mV}$ every $88 \mathrm{sec} . A-D$, Representative traces from four different cells. Two DSI trials per condition are shown. CCh enhanced DSI at $0.2-25 \mu \mathrm{M}$ and reduced eIPSC amplitude as well at $\geq 1 \mu \mathrm{M}$. The antagonistic effect of atropine $(1 \mu \mathrm{M})$ was tested with 0.5 and $1 \mu \mathrm{M}$ CCh. $E$, Changes in DSI $(\triangle D S I)$ were calculated by subtracting control DSI from DSI with CCh ( filled bars). DSI with CCh was greater than control DSI at $0.2,0.5,1$, and $25 \mu \mathrm{M} \mathrm{CCh}\left(n=7,7,11\right.$, and 5, respectively) $\left({ }^{*} p<0.01\right.$; paired $t$ test). At $0.5 \mu \mathrm{M}(n=5)$ and $1 \mu \mathrm{M}(n=5)$ CCh, $1 \mu \mathrm{M}$ atropine reversed the effect of CCh (open bars; paired $t$ test after repeated measures ANOVA; $p>0.1$ ). $F$, eIPSC amplitude was not changed by 0.2 and $0.5 \mu \mathrm{M}$ CCh (paired $t$ test; $p>0.1)$ but reduced by 1 and $25 \mu \mathrm{M}\left({ }^{*} p<0.001\right.$; paired $t$ test; filled bars). Atropine $(1 \mu \mathrm{M})$ recovered the eIPSC amplitude reduced by $1 \mu \mathrm{M}$ CCh (open bars; paired $t$ test after repeated measures ANOVA; $p>0.1$ ). $G$, Peak $\mathrm{Ca}^{2+}$ current activated by $0 \mathrm{mV}$ pulse. In the presence of $0.2-1 \mu \mathrm{M} C \mathrm{Ch}$, the mean $\mathrm{Ca}^{2+}$ currents were $88-94 \%$ of control ( filled bars). In the presence of $0.5 \mu \mathrm{M} \mathrm{CCh}$ plus atropine, the $\mathrm{Ca}^{2+}$ current showed more rundown (75 $\pm 4 \%$ of control; open bars $)$. CCh $(25 \mu \mathrm{M})$ reduced the eIPSC amplitude to $61 \pm 8 \%$ of control. ${ }^{*} p<0.05$; paired $t$ test between control and CCh.

over control DSI. Unlike submicromolar concentrations, higher concentrations of CCh $(1$ and $25 \mu \mathrm{M})$ not only enhanced DSI but also reduced eIPSC amplitudes (Fig. $1 C, D$ ). $\Delta$ DSI was $32 \pm 6 \%$ $(n=11)$ in $1 \mu \mathrm{M} \mathrm{CCh}$ and $30 \pm 5 \%(n=5)$ in $25 \mu \mathrm{M} \mathrm{CCh}$ (paired $t$ test with each control; $p<0.01$ ) (Fig. $1 E$ ), although there was no significant difference among $\Delta$ DSIs at the four different concentrations (ANOVA; $p>0.1$ ). One and $25 \mu \mathrm{M}$ CCh significantly reduced eIPSC amplitude to $68 \pm 4 \%$ and $29 \pm 3 \%$ of control, respectively (paired $t$ test; $p<0.001$ ) (Fig. $1 F$ ). To test whether all effects of $\mathrm{CCh}$ are mediated by mAChRs, we applied $1 \mu \mathrm{M}$ atropine, an $\mathrm{mAChR}$ antagonist, in the presence of $\mathrm{CCh}$ (Fig. $1 B, C)$. Atropine completely reversed the effects of 0.5 or $1 \mu \mathrm{M}$ $\mathrm{CCh}$ on DSI and eIPSC amplitudes to the control level (paired $t$ test with control; $p>0.1$ after repeated measures ANOVA among control, CCh, and atropine groups).

It is unlikely that DSI enhancement and IPSC reduction by $\mathrm{CCh}$ was mediated through changes in ionic currents (e.g., $\mathrm{M}$-current, $\mathrm{K}^{+}$leak current, and $\mathrm{Ca}^{2+}$-activated $\mathrm{K}^{+}$current). In the cells shown in Figure 1, $0.5 \mu \mathrm{M}$ CCh did not change the holding current significantly; it went from $-163 \pm 27 \mathrm{pA}$ in control to $-151 \pm 22 \mathrm{pA}$ in CCh $(p>0.1$; paired $t$ test). CCh, 1 $\mu \mathrm{M}$, increased inward holding current significantly, but only slightly, from $-187 \pm 18 \mathrm{pA}$ in control to $-198 \pm 18 \mathrm{pA}$ in CCh $(p<0.05$; paired $t$ test). The DSI enhancement or IPSC reduction by $\mathrm{CCh}$ cannot be attributed to these small changes in holding current.

The enhancement of DSI did not appear to be caused by an increase in the voltage-dependent $\mathrm{Ca}^{2+}$ current that initiates DSI. In the presence of $0.2-1 \mu \mathrm{M} \mathrm{CCh}$, the mean $\mathrm{Ca}^{2+}$ currents were $88-94 \%$ of control, which could represent normal rundown of $\mathrm{Ca}^{2+}$ current (Fig. $1 G$ ), but in $25 \mu \mathrm{M} \mathrm{CCh}$, the mean $\mathrm{Ca}^{2+}$ current was only $61 \pm 8 \%$ of control. It is therefore unlikely that the increase in DSI caused by CCh is associated with a change in
$\left[\mathrm{Ca}^{2+}\right]_{\mathrm{i}}$. Nevertheless, the $\mathrm{Ca}^{2+}$ current may be imperfectly voltage clamped, and $\mathrm{CCh}$ might have influenced depolarizationinduced $\left[\mathrm{Ca}^{2+}\right]_{\mathrm{i}}$ transients. To examine this issue further, we imaged $\left[\mathrm{Ca}^{2+}\right]_{\mathrm{i}}$ from pyramidal cell somata simultaneously with measurements of DSI. We used brief voltage steps $(0.25-0.5 \mathrm{sec})$ to induce a minimal degree of DSI and then bath applied 0.2 or $0.5 \mu \mathrm{M}$ CCh. The low concentration of CCh enhanced DSI but did not affect the fluorescence signals for basal $\left[\mathrm{Ca}^{2+}\right]_{\mathrm{i}}(n=5$; data not shown) or the transients in response to voltage steps, as measured by the $\Delta F / F$ ratio (Fig. 2). The lack of change in $\Delta F / F$ was not the result of dye saturation, because a larger $\mathrm{Ca}^{2+}$ response was detected when a longer voltage step was given (Fig. $2 B$, inset). These results demonstrate that increases in depolarization-induced $\mathrm{Ca}^{2+}$ transients are not necessary for CCh to enhance DSI.

Because DSI is mediated by the release of endocannabinoids, it was possible that the effects of mAChR activation on DSI and eIPSCs were mediated through an interaction with the endocannabinoid system. We tested this hypothesis by applying $\mathrm{CCh}$ either to cells in normal slices in the presence of the CB1R antagonist AM251 (4 $\mu \mathrm{M})$ or to cells in slices from CB1 $\mathrm{R}^{-/-}$mice (Fig. 3). As reported (Ohno-Shosaku et al., 2001; Wilson and Nicoll, 2001), CB1R antagonists blocked DSI in rat hippocampus (mean DSI in control condition $=1-3 \%$ ) (Fig. $3 A$ ), and DSI was absent in the CB1R ${ }^{-1-}$ mouse (Varma et al., 2001; Wilson et al., 2001) (control DSI $=0 \pm 1 \% ; n=4$ ) (Fig. 3B). For comparison, DSI from rat slices in normal conditions (Fig. 1) was $30 \pm 3 \%$ ( $n=30$ cells). In rat slices treated with AM251, application of 1-25 $\mu \mathrm{M} \mathrm{CCh}$ did not produce significant DSI. $\Delta$ DSIs were $2 \pm$ $1 \%(n=5)$ for $1 \mu \mathrm{M} \mathrm{CCh}, 4 \pm 3 \%(n=4)$ for $5 \mu \mathrm{M} \mathrm{CCh}$, and $6 \pm$ $4 \%(n=5)$ for $25 \mu \mathrm{M} \mathrm{CCh}(p>0.1$; paired $t$ test in each group) (Fig. $3 C$ ). In $\mathrm{CB} 1 \mathrm{R}^{-1-}$ mouse slices, $1-25 \mu \mathrm{M}$ CCh also did not cause DSI to appear (repeated measures ANOVA; $p>0.1$ ) (Fig. 

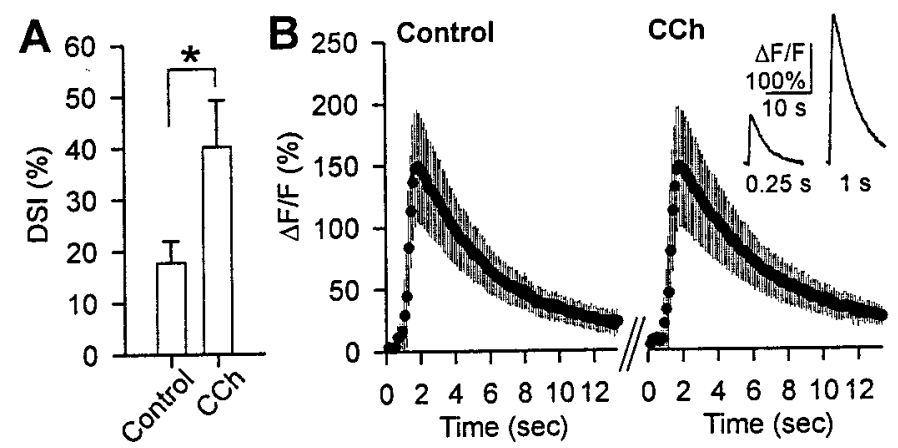

Figure 2. The enhancement of DSI by CCh is not associated with an increase in the depolarization-induced somatic $\mathrm{Ca}^{2+}$ transients. eIPSCs were evoked every $5 \mathrm{sec}$, and a 250 -msec-long depolarizing voltage step to $0 \mathrm{mV}$ was delivered at intervals of several minutes. $A$, The average magnitude of DSI in control solution was enhanced more than twofold in $0.2 \mu \mathrm{M}$ CCh $\left({ }^{*} p<0.05\right.$; Wilcoxon signed rank test; $\left.n=5\right)$. $B$, Group data for the simultaneously measured $\Delta F / F$ ratio of the $\left[\mathrm{Ca}^{2+}\right]_{\mathrm{i}}$ signals are shown for control conditions (left graph) and in the same cells in the presence of CCh (right graph). The DSI-inducing voltage step was given $1.5 \mathrm{sec}$ after time 0 . Note that the increase in DSI is not accompanied by an increase in $\Delta F / F$. The inset on the right graph, showing an example of a larger $\Delta F / F$ change that was produced by a $1 \mathrm{sec}$ voltage step in the same cells, demonstrates that the lack of measured changes in $\Delta F / F$ did not result from dye saturation.

$3 C)$. Mean $\Delta$ DSIs were in the range of -1 to $2 \%(n=4)$. CCh at $1 \mu \mathrm{M}$ did not reduce eIPSCs in rat slices treated with AM251 or in CB1R ${ }^{-1-}$ mice (Fig. 3D). The mean eIPSC was $102 \pm 2 \%$ of control in treated rat slices and $98 \pm 2 \%$ in $\mathrm{CB}^{-1-} \mathrm{R}^{-1}$ mice. In control $\mathrm{CB} 1 \mathrm{R}^{+/+}$mice of the CD-1 strain, which is the background for CB1 $\mathrm{R}^{-1-}$ mice (Ledent et al., 1999), CCh $(1 \mu \mathrm{M})$ increased DSI by $18 \pm 4 \%(n=3 ; p<0.05$; data not shown $)$. This implies that the enhancement of DSI by $1 \mu \mathrm{M}$ CCh (Fig. $1 F)$ was mediated entirely by induced endocannabinoid release.

The mean eIPSC in $5 \mu \mathrm{M}$ CCh was $69 \pm 9 \%$ of control in rat slices treated with AM251 and $88 \pm 7 \%$ in $\mathrm{CB}^{-1 \mathrm{R}^{-1-}}$ slices, but these decreases were not significant $(p>0.1)$. CCh at $25 \mu \mathrm{M}$ significantly reduced eIPSC amplitudes to $60 \pm 5 \%$ of control in AM251-treated rat slices ( $p<0.01$; paired $t$ test) and to $69 \pm 4 \%$ in CB1R ${ }^{-1-}$ slices $(p<0.05$; paired $t$ test after repeated measures ANOVA). Thus, $25 \mu \mathrm{M}$ CCh reduced eIPSCs not only by a direct induction of persistent endocannabinoid release but by other mechanisms as well.

From the difference in the eIPSC depression caused by $25 \mu \mathrm{M}$ $\mathrm{CCh}$ in control conditions (71\%), and in the AM251-treated condition (40\%), we infer that $25 \mu \mathrm{M}$ CCh reduced eIPSC by $31 \%$ via the endocannabinoid pathway. Tests on the group data showed that this is statistically indistinguishable from the $32 \%$ eIPSC depression caused by $1 \mu \mathrm{M}$ CCh $(p>0.1 ; t$ test). This leads to the conclusion that persistent, mAChR-induced release of endocannabinoids is saturated by $1 \mu \mathrm{M} \mathrm{CCh}$. In the remaining experiments, we used $1 \mu \mathrm{M} \mathrm{CCh}$, except where noted, to induce persistent endocannabinoid release maximally and to avoid the confounding effects of other mAChR-mediated mechanisms of eIPSC suppression that are produced by higher $\mathrm{CCh}$ concentrations.

mGluR activation can enhance release of endocannabinoids (Maejima et al., 2001; Varma et al., 2001; Ohno-Shosaku et al., 2002); therefore, it was necessary to determine whether mGluR activation could be involved in the action of $\mathrm{CCh}$. For example, $\mathrm{CCh}$ might cause glutamatergic neurons to release glutamate, and this could activate mGluRs on the pyramidal cell and thereby
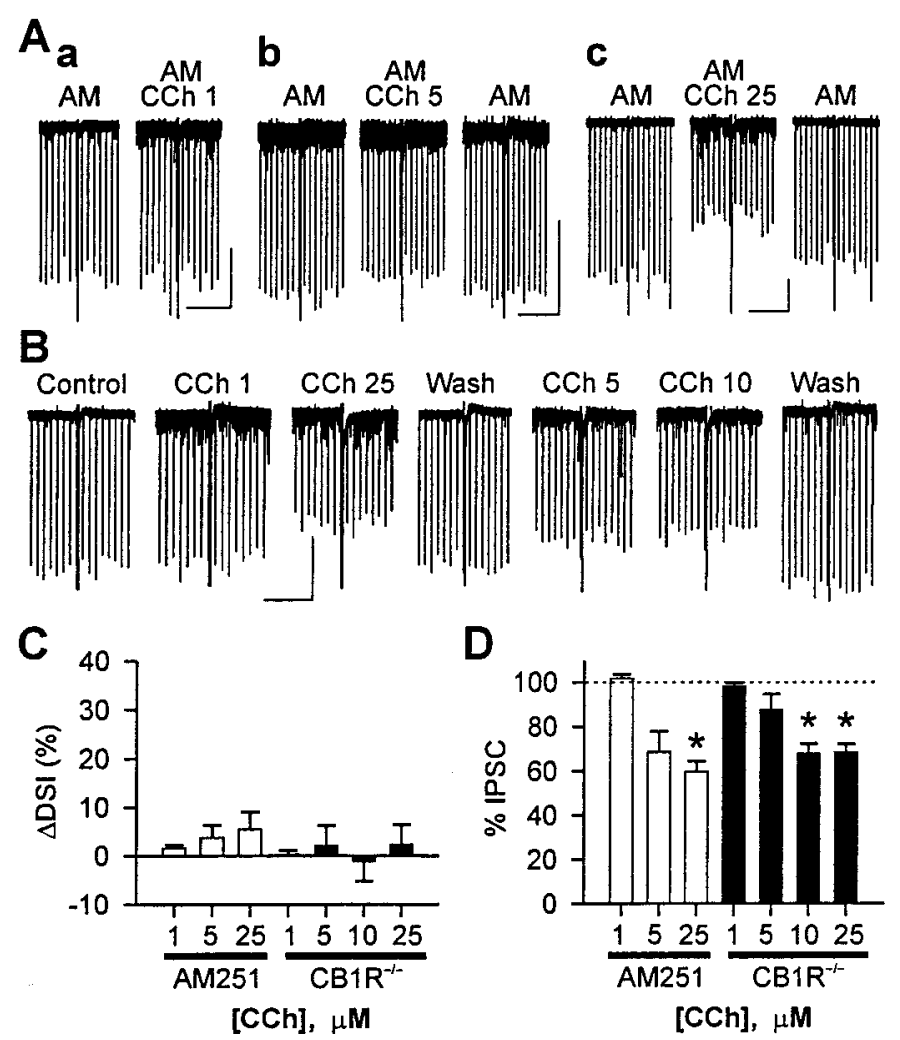

Figure 3. The effects of CCh on DSI and eIPSCs are reduced by AM251 and in $\mathrm{CB} 1 \mathrm{R}^{-1-}$ mice. $A$, Representative traces from three cells in rat slices treated with the CB1R antagonist AM251 (4 $\mu \mathrm{M})$. One DSI trial per condition is shown. DSI was abolished by AM251, and CCh $(1-25 \mu \mathrm{M})$ did not produce notable DSI. eIPSC amplitude was not changed by $1 \mu \mathrm{M} \mathrm{CCh}$ (a) but was reduced by $5 \mu \mathrm{M}(b)$ or $25 \mu \mathrm{M}$ CCh $(c)$. Calibration: $200 \mathrm{pA}$, $30 \mathrm{sec}$. $B$, Representative traces of a cell from a CB1R ${ }^{-1-}$ mouse. One DSI trial per condition is shown. DSI is absent in the presence or absence of CCh. eIPSCs were reduced by 5-25 $\mu \mathrm{M}$ CCh. Calibration: $200 \mathrm{pA}, 30$ sec. $C$, DSI was not changed significantly by $1-25 \mu \mathrm{M} C C h$ in the presence of $4 \mu \mathrm{M}$ AM251 (open bars) or in CB1R ${ }^{-1-}$ mice ( filled bars). In AM251 data, $n=5$ for 1 or $25 \mu \mathrm{M} \mathrm{CCh}$, and $n=4$ for $5 \mu \mathrm{M} \mathrm{CCh}$. For each concentration of $\mathrm{CCh}$ in $\mathrm{AM} 251$ data, $p>0.1$ (paired $t$ tests). In CB1R ${ }^{-1-}$ data, $n=4$, and $p>0.1$ (repeated measures ANOVA). $D$, eIPSC amplitude was not changed by $1 \mu \mathrm{M} C \mathrm{Ch}$ in rat slices with AM251 (open bar; $p>0.1$; paired $t$ test) or in slices from CB1R ${ }^{-1-}$ mice ( filled bar; $p>0.1$; paired $t$ test after repeated measures ANOVA). The effects of $5 \mu \mathrm{M}$ CCh on eIPSC amplitude were variable from cell to cell and were not significant $(p>0.1$; same tests as $1 \mu \mathrm{M})$. eIPSC was significantly reduced by $25 \mu \mathrm{M}$ CCh $(p<0.05$; same tests as $1 \mu \mathrm{M})$.

stimulate endocannabinoid release. To test this possibility, we applied CCh together with $100 \mu \mathrm{M}$ LY341495, an mGluR antagonist that at high concentration blocks all known mGluRs (Fitzjohn et al., 1998). We found that $\mathrm{CCh}$ at $1 \mu \mathrm{M}$ was capable of increasing DSI and reducing eIPSC amplitudes in the presence of LY341495 (Fig. 4A). $\Delta$ DSI was $24 \pm 7 \%(n=5$; paired $t$ test after repeated measures ANOVA; $p<0.05$ ) (Fig. $4 C$ ). We confirmed that LY341495 had blocked mGluRs by observing that $10 \mu \mathrm{M}$ ACPD had no effect on DSI (Fig. 4A) (cf. Varma et al., 2001). $\Delta$ DSI was $1 \pm 4 \%(n=5$; paired $t$ test after repeated measures ANOVA; $p>0.5$ ) (Fig. $4 C$ ). Therefore, mGluR activation is not necessary for $\mathrm{CCh}$ to enhance endocannabinoid release. To determine whether the mGluR and $\mathrm{mAChR}$ effects on DSI are independent, we also performed the converse experiment to rule out the possibility that activation of mGluRs on cholinergic neurons releases acetylcholine and thereby stimulates endocannabi- 

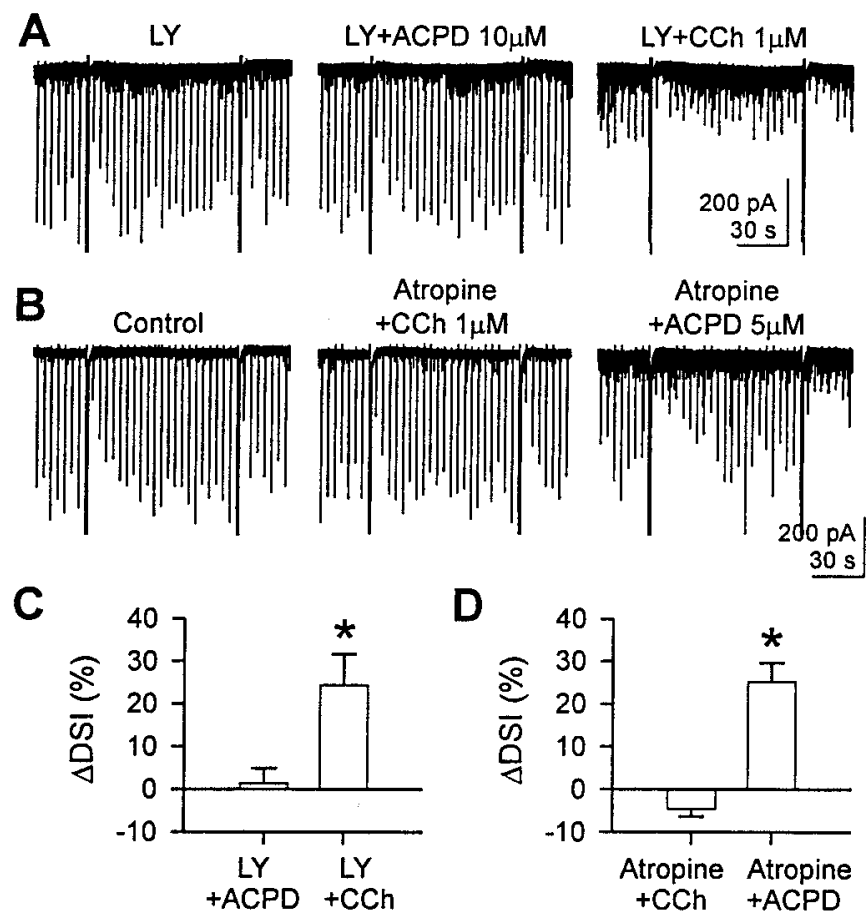

Figure 4. Activation of mAChR or mGluR can enhance DSI independently of each other. $A$, In the presence of LY341495 (100 $\mu \mathrm{M}), 1 \mu \mathrm{M}$ CCh enhanced DSI and reduced the eIPSC amplitude, but the ability of $10 \mu \mathrm{M}$ ACPD to enhance DSI was antagonized by $100 \mu \mathrm{M} \mathrm{LY341495.} \mathrm{Traces} \mathrm{are}$ from one cell. $B$, In the presence of atropine $(1 \mu \mathrm{M}), 5 \mu \mathrm{M}$ ACPD enhanced DSI, but $1 \mu \mathrm{M}$ CCh did not. $C$, In five cells, ACPD $(10 \mu \mathrm{M})$ and CCh $(1 \mu \mathrm{M})$ were sequentially applied in the presence of $100 \mu \mathrm{M}$ LY341495. CCh enhanced DSI significantly $\left({ }^{*} p<0.05\right.$; paired $t$ test after repeated measures ANOVA). No effect of ACPD (paired $t$ test after repeated measures ANOVA; $p>0.5$ ) indicates that LY341495 was effectively blocking mGluR. $D$, In five cells, CCh $(0.5$ or $1 \mu \mathrm{M})$ and ACPD (5 or $10 \mu \mathrm{M}$ ) were sequentially applied in the presence of $1 \mu \mathrm{M}$ atropine. Data for two concentrations were pooled. ACPD enhanced DSI significantly $\left({ }^{*} p<0.05\right.$; paired $t$ test after repeated measures ANOVA), whereas $\mathrm{CCh}$ did not (paired $t$ test after repeated measures ANOVA; $p>0.5)$.

noid release from pyramidal cells. Indeed, in the presence of $1 \mu \mathrm{M}$ atropine, 5 or $10 \mu \mathrm{M}$ ACPD enhanced DSI (Fig. $4 B$ ). $\Delta$ DSI was $25 \pm 4 \%(n=5$; paired $t$ test after repeated measures ANOVA; $p<0.05$ ) (Fig. 4D).

Thus, mGluRs and mAChRs independently act on the endocannabinoid system; however, they may share intracellular machinery for endocannabinoid release. We addressed this issue by determining whether the two pathways would occlude each other when they were maximally stimulated. In the presence of a high concentration $(25 \mu \mathrm{M})$ of CCh, we applied $50 \mu \mathrm{M}$ ACPD, which at this concentration reduces eIPSC amplitudes and largely occludes DSI (Morishita et al., 1998) (Fig. 5A,B). In $25 \mu \mathrm{M} \mathrm{CCh}$, DSI of eIPSC or sIPSC is very clear, but it did not change when $50 \mu \mathrm{M}$ ACPD was applied (paired $t$ test; $p>0.5$ ). $\Delta$ DSI was $-2 \pm$ $4 \%$ for eIPSC $(n=5)$ and $-1 \pm 2 \%$ for $\operatorname{sIPSC}(n=7)$ (Fig. $5 D)$. In addition, neither the amplitude of the eIPSC $(107 \pm 9 \%$ of control) nor the magnitude of the charge carried by SIPSC (102 \pm $9 \%$ of control) was changed by $50 \mu \mathrm{M}$ ACPD (paired $t$ test; $p>$ 0.1 ) (Fig. $5 E$ ). This could imply that the endocannabinoid release system was already saturated by $25 \mu \mathrm{M} \mathrm{CCh}$, such that no more endocannabinoids were available for release by the mGluR pathway. However, significant DSI $(60 \pm 1 \%, n=5$, for eIPSCs; $71 \pm$ $3 \%, n=7$, for sIPSCs) could still be obtained in the presence of

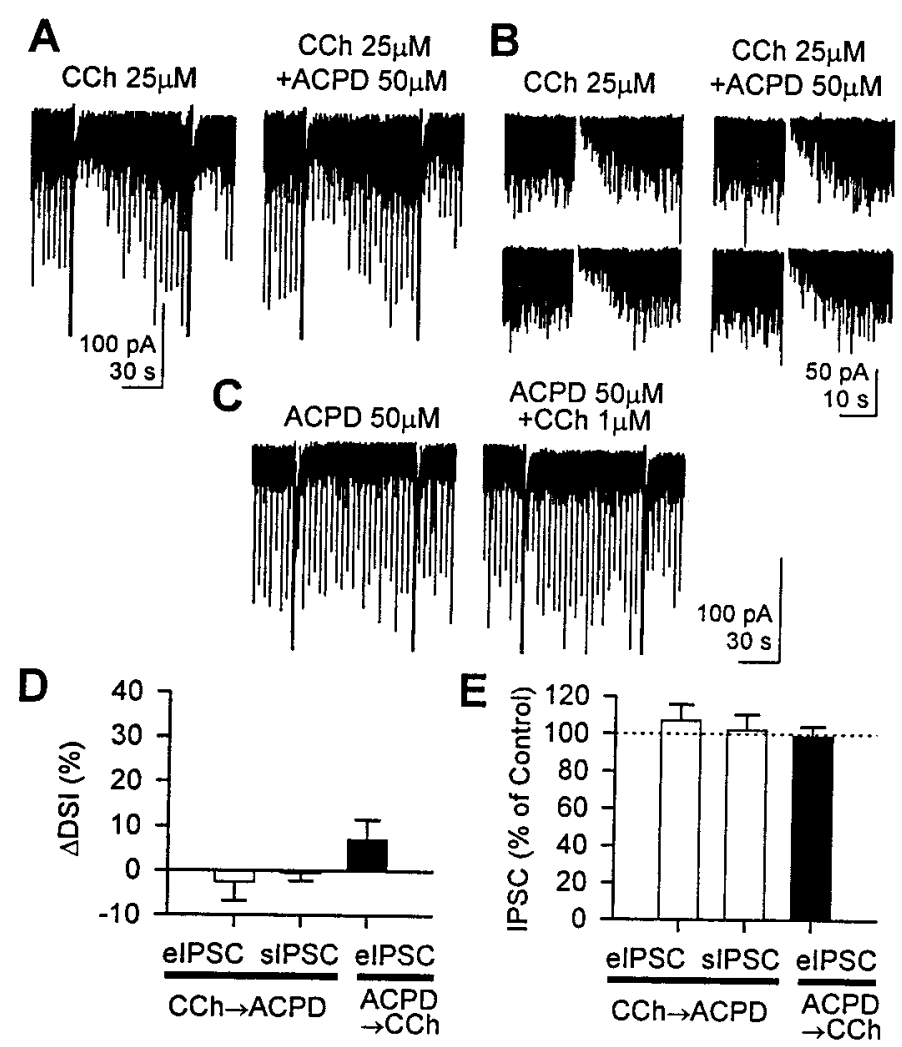

Figure 5. A high concentration of either $\mathrm{CCh}$ or $\mathrm{ACPD}$ prevented the other from enhancing DSI and reducing eIPSC amplitude. $A$, ACPD (50 $\mu \mathrm{M})$, which normally reduces eIPSC amplitude and occludes DSI at this concentration, did not affect DSI or eIPSC when applied with $25 \mu \mathrm{M} \mathrm{CCh}$. Note that $50 \mu \mathrm{M}$ ACPD had little effect on either eIPSC or SIPSC. $B$, In this cell, only sIPSCs were measured. DSI and eIPSC amplitudes were unaffected by $50 \mu \mathrm{M}$ ACPD in the presence of $25 \mu \mathrm{M} \mathrm{CCh}$. $\mathrm{Ca}^{2+}$ current and associated transient current were blanked for clarity. For clear comparison of DSI, a fast inward current activated by depolarization was subtracted from the baseline. The two DSI trials in each column are consecutive. $C$, In this cell, $50 \mu \mathrm{M}$ ACPD was applied before $1 \mu \mathrm{M} \mathrm{CCh}$. CCh slightly enhanced DSI but had no effect on eIPSC amplitude. $D$, Group data of $\Delta \mathrm{DSI}$. When $25 \mu \mathrm{M}$ CCh was applied first (open bars), 50 $\mu \mathrm{M}$ ACPD had no effect on DSI of eIPSC $(n=5$; paired $t$ test; $p>0.5)$ or DSI of $\operatorname{sIPSC}(n=7$; paired $t$ test; $p>0.5)$. When $50 \mu \mathrm{M}$ ACPD was applied first (filled bar), $1 \mu \mathrm{M}$ CCh slightly increased DSI of eIPSC, but it was not significant $(n=5$; paired $t$ test; $p>0.1)$. In the experiments in which CCh was applied first, both SIPSC and eIPSC were measured in four cells, only sIPSC was measured in three cells, and only eIPSC was measured in one cell. $E$, When $25 \mu \mathrm{M} C C h$ was applied first (open bars), $50 \mu \mathrm{M}$ ACPD had no effect on amplitude of eIPSC $(n=5$; paired $t$ test; $p>0.1)$ or charge of $\operatorname{sIPSC}(n=7$; paired $t$ test; $p>0.5)$. When $50 \mu \mathrm{M}$ ACPD was applied first (filled bar), $1 \mu \mathrm{M}$ CCh did not change the amplitude of eIPSC ( $n=5$; paired $t$ test; $p>0.1)$. Charge carried by sIPSC was measured by integrating the area under sIPSC for $20 \mathrm{sec}$ before and $16 \mathrm{sec}$ after the $0 \mathrm{mV}$ pulse. "Charge per second" was used as a magnitude of sIPSC.

high CCh (Fig. 5A,B), showing that despite apparent inability to stimulate the persistent release pathway further, the transient release of endocannabinoids by the $\mathrm{Ca}^{2+}$-dependent pathway that initiates DSI could still be activated. Therefore, endocannabinoid release in general was not saturated. This result implies the existence of two independent pathways for endocannabinoid release.

To determine whether maximal mGluR activation was similarly capable of occluding endocannabinoid release stimulated by mAChRs, we tested the reverse order of agonist application. 
When ACPD $(50 \mu \mathrm{M})$ was applied first, DSI of the eIPSC was partly occluded (DSI was $29 \pm 5 \%$ in control and $21 \pm 3 \%$ in ACPD; $n=5$ ) (Fig. 5C), and $1 \mu \mathrm{M}$ CCh did not significantly enhance it $(n=5$; $\Delta$ DSI $=7 \pm 4 \%$; paired $t$ test; $p>0.1)$ (Fig. $5 D)$. Furthermore, the eIPSC amplitude was not changed by $1 \mu \mathrm{M}$ $\mathrm{CCh}$ in the presence of $50 \mu \mathrm{M}$ ACPD (99 $\pm 5 \%$ of control; paired $t$ test; $p>0.1$ ) (Fig. 5E). Evidently, $50 \mu \mathrm{M}$ ACPD induced the persistent release of endocannabinoid to such an extent that GABA release from DSI-susceptible interneurons was largely inhibited, thus occluding DSI and additional effects of $\mathrm{CCh}$ on eIPSCs. We conclude that the mAChR and mGluR pathways share intracellular machinery for cannabinoid release, but they do not activate them equivalently (see Discussion).

Do DSI and the persistent release pathways for endocannabinoid release rely only on $\mathrm{Ca}^{2+}$ or also G-proteins? To investigate this issue, we included $1 \mathrm{~mm}$ GTP $\gamma \mathrm{S}$, which locks G-proteins into a persistently active state and thus inhibits further activation by an agonist, in the pipette solution (Fig. 6). We waited for $\sim 30 \mathrm{~min}$ for complete dialysis of the cell with GTP $\gamma \mathrm{S}$. The voltagedependent $\mathrm{Ca}^{2+}$ current was gradually inhibited as expected (Dolphin, 1995) and finally abolished during this time; consequently, DSI was abolished. Every cell, however, showed DSI until $\sim 15$ min after the onset of whole-cell configuration. This means that all pyramidal cells tested in the GTP $\gamma \mathrm{S}$ experiment were able to release endocannabinoids and that the presynaptic interneurons possessed CB1R. Nevertheless, with GTP $\gamma \mathrm{S}$ inside the postsynaptic cell, bath application of $1 \mu \mathrm{M}$ CCh did not reduce the eIPSC amplitude (100 $\pm 3 \%$ of control; $n=6$; paired $t$ test; $p>0.1$ ) (Fig. 6A,B). The reduction of eIPSC amplitude by subsequent application of $2 \mu \mathrm{M}$ WIN 55212-2 confirmed that the eIPSCs could be reduced by CB1R activation, thus showing that the interneurons possessing CB1Rs were still active (Fig. 6A,B). WIN 55212-2 $(2 \mu \mathrm{M})$ reduced the eIPSC amplitude to $75 \pm 6 \%$ of control $(n=5$; paired $t$ test; $p<0.05)$. We attempted to test the hypothesis further by including $1 \mathrm{~mm} \mathrm{GDP}_{\beta} \mathrm{S}$ in the pipette because it can block G-proteins. However, in four of six cells, $\mathrm{GDP}_{\beta} \mathrm{S}$ did not block DSI or the ability of CCh to enhance it; in fact, DSI was enhanced by $\operatorname{GDP}_{\beta} \mathrm{S}$ (data not shown). Similar anomalous enhancing effects of $\mathrm{GDP}_{\beta} \mathrm{S}$ on presumed G-proteinmediated responses have been reported (Andrade et al., 1986; Paris and Pouyssegur, 1990). In any event, this complication meant that we could not use $\mathrm{GDP}_{\beta} \mathrm{S}$ to study the role of G-proteins. The results in Figure 6 show that the $\mathrm{CCh}$ effect on persistent endocannabinoid release was mediated by postsynaptic G-proteins.

Because GTP $\gamma \mathrm{S}$ is an activator of G-proteins, GTP $\gamma \mathrm{S}$ itself could induce G-protein-dependent endocannabinoid release directly. If this is true, an alternative interpretation of the GTP $\gamma \mathrm{S}$ results (Fig. 6A,B) is possible. Stimulation of the G-protein pathway by GTP $\gamma \mathrm{S}$ might occlude the ability of $\mathrm{CCh}$ to release more endocannabinoids. Thus, in GTP $\gamma \mathrm{S}$-loaded cells, CCh would appear to have no effect (Fig. $6 A, B$ ), but this would not be attributable to inhibition of the CCh pathway by GTP $\gamma \mathrm{S}$.

To test this possibility, we checked whether GTP $\gamma \mathrm{S}$ by itself can release endocannabinoids. After allowing $1 \mathrm{~mm} \mathrm{GTP} \gamma \mathrm{S}$ to diff use into the postsynaptic cell for 20-30 min, we bath-applied $4 \mu \mathrm{M}$ AM251 (Fig. 6E). When applied to cells loaded with $1 \mathrm{~mm}$ intracellular GTP $\gamma \mathrm{S}$, AM251 increased eIPSC amplitudes to $143 \pm 8 \%$ at 16 min of application $(n=5 ; p<0.01$; paired $t$ test $)$, suggesting that persistent release of endocannabinoids caused by GTP $\gamma \mathrm{S}$ had been suppressing the eIPSCs. Before accepting this conclusion, it was necessary to rule out another possible interpre-
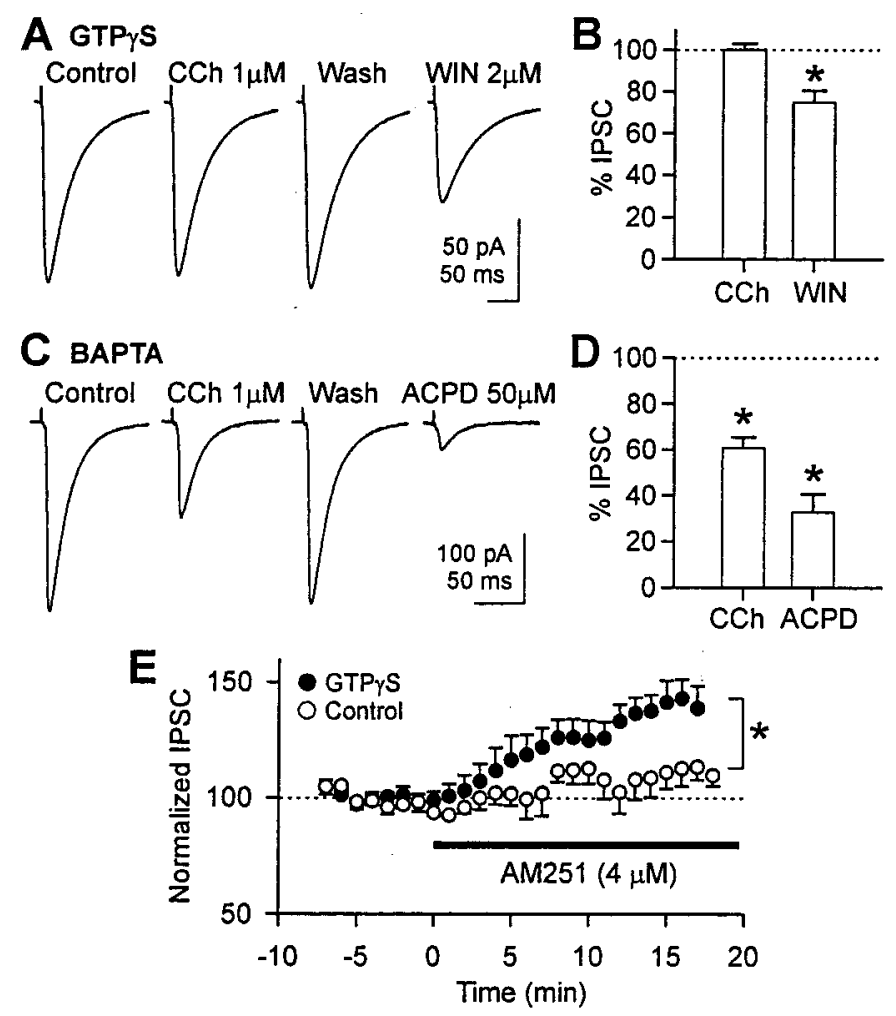

Figure 6. Effect of CCh on eIPSC amplitude in cells loaded with GTP $\gamma \mathrm{S}$ $(1 \mathrm{~mm})$ or high BAPTA $(35 \mathrm{~mm}) . A$, With $1 \mathrm{~mm}$ GTP $\gamma \mathrm{S}$ inside the postsynaptic cell, CCh $(1 \mu \mathrm{M})$ did not reduce eIPSC amplitude, but WIN 55212-2 (2 $\mu \mathrm{M})$ did. In all experiments, WIN 55212-2 was applied in the absence of $\mathrm{CCh}$ to prevent confounding of effects. Forty traces were averaged for this cell, and 30-60 traces were averaged for other cells. The stimulus artifacts were partially truncated graphically. We waited for $\sim 30$ min for complete action of GTP $\gamma \mathrm{S}$. DSI had disappeared by this time because of inhibition of the $\mathrm{Ca}^{2+}$ current. $B$, With $1 \mathrm{~mm}$ intracellular GTP $\gamma \mathrm{S}, 1 \mu \mathrm{M}$ CCh did not affect eIPSC amplitude $(n=6$; paired $t$ test; $p>0.1)$, but WIN55212-2 $(2 \mu \mathrm{M})$ reduced it to $75 \pm 6 \%(n=5$; paired $t$ test; $\left.{ }^{*} p<0.05\right) . C, \mathrm{CCh}(1 \mu \mathrm{M})$ reduced eIPSC amplitude in a reversible manner in the presence of $35 \mathrm{~mm}$ BAPTA inside the postsynaptic cell. In addition, high BAPTA did not prevent $50 \mu \mathrm{M}$ ACPD from reducing eIPSC. Forty to 50 traces were averaged for this cell, and 40-60 traces were averaged for other cells. DSI was not observed with high BAPTA in either the presence or absence of CCh. $D$, In cells loaded with $35 \mathrm{~mm}$ BAPTA, $1 \mu \mathrm{M}$ CCh reduced eIPSC amplitude to $61 \pm 5 \%(n=6$; paired $t$ test; * $p<0.01)$, and $50 \mu \mathrm{M}$ ACPD reduced it to $33 \pm 8 \%(n=5$; paired $t$ test; $* p<0.05)$. $E$, In cells loaded with 1 mM GTP $\gamma \mathrm{S}$, AM251 $(4 \mu \mathrm{M})$ increased eIPSC amplitude ( filled circles; $n=5$ ), indicating that GTP $\gamma \mathrm{S}$ by itself stimulated endocannabinoid release. At 16 min of AM251 application, eIPSC amplitude was $143 \pm 8 \%$ of the control amplitude. AM251 was also applied to control cells lacking GTP $\gamma \mathrm{S}$ (open circles; $n=5$ ). At 16 min, eIPSC amplitude in these cells was $113 \pm 8 \%$ of the baseline. Each circle is mean value of five cells after averaging 15 traces $(1 \mathrm{~min})$ within a cell. ${ }^{*} p<0.05 ; t$ test for $16-17 \mathrm{~min}$.

tation. The CB1R antagonist AM251, like SR141716A, is actually an inverse agonist (Bouaboula et al., 1997; Pan et al., 1998). Moreover, CB1R is constitutively active and can bind GTP in the absence of ligand (Pan et al., 1998). Because an inverse agonist binds to and stabilizes the receptor in a GDP-bound, inactive state, it can produce opposite effects of those produced by ligandbound receptor. To determine whether the increase of eIPSC produced by AM251 reflected this inverse agonist effect, we applied $4 \mu \mathrm{M}$ AM251 to cells recorded with a normal pipette solution (i.e., without GTP $\gamma$ S). AM251 slightly increased eIPSC amplitudes to $113 \pm 8 \%$ at $16 \mathrm{~min}$ of application, but the effect 
was variable from cell to cell and not significant $(n=5 ; p>0.1$; paired $t$ test). Therefore, the inverse agonist effect does not play a substantial role in the actions of AM251, although we cannot rule out a slight contribution. The difference between the eIPSC amplitudes in cells loaded with GTP $\gamma \mathrm{S}$ and control cells was significant (comparison made at 16-17 min of AM251 application; $p<0.05$; $t$ test). We infer that the enhancement of eIPSCs caused by AM251 is attributable to its blockade of CB1Rs that have been activated by a persistent, GTP $\gamma \mathrm{S}$-induced release of endocannabinoids. This action of GTP $\gamma \mathrm{S}$ occludes the ability of CCh to suppress eIPSCs.

As a check on this interpretation, we can estimate the magnitude of the endocannabinoid-dependent eIPSC suppression caused by loading cells with GTP $\gamma \mathrm{S}$. AM 251 increased the eIPSC $43 \%$ above control $(100 \%)$ in these cells. This suggests that GTP $\gamma$ S-released endocannabinoids caused a $30 \%$ reduction in eIPSC [1 - (100/143\%)]. Even if this is corrected for a possible AM251 inverse-agonist effect (we took $13 \%$ as a conservative estimate; see preceding paragraph), the net increase in GTP $\gamma \mathrm{S}$ loaded cells would be $30 \%(43-13 \%)$, and GTP $\gamma \mathrm{S}$ would have suppressed eIPSCs by $23 \%$ [1 - (100/130\%)]. These estimates are similar to but perhaps smaller than the $32 \%$ reduction in eIPSC caused by $1 \mu \mathrm{M}$ CCh (Fig. 1). It is possible that GTP $\gamma \mathrm{S}$ totally occludes the effects of $1 \mu \mathrm{M}$ CCh by maximally activating the G-protein-dependent, endocannabinoid release pathway or, alternatively, that the occlusion is only partial, and some other consequence of GTP $\gamma \mathrm{S}$ loading helps prevent the CCh effects. In any case, the absence of CCh effects on eIPSCs in the GTP $\gamma \mathrm{S}$ loaded cells implies that $\mathrm{CCh}$ acts on the postsynaptic mAChRs, because postsynaptic treatment interfered with the effect of $\mathrm{CCh}$.

We then tested whether the persistent release of cannabinoid induced by $\mathrm{CCh}$ is initiated by intracellular $\mathrm{Ca}^{2+}$, because DSI is. To suppress increases in intracellular $\mathrm{Ca}^{2+}$, we included $35 \mathrm{~mm}$ BAPTA in the pipette solution (Fig. $6 C, D$ ), which abolished DSI, as expected. However, even with $35 \mathrm{~mm}$ intracellular BAPTA, CCh $(1 \mu \mathrm{M})$ reduced eIPSC amplitudes to $61 \pm 5 \%$ of control (paired $t$ test; $p<0.01$ ) in a reversible manner. This did not differ significantly from the depression (to $68 \%$ ) that we observed in control conditions (Fig. 1) ( $t$ test; $p>0.1$ ). In addition, $50 \mu \mathrm{M}$ ACPD depressed eIPSC amplitude to $33 \pm 8 \%$ of control in the high internal BAPTA condition, which did not differ significantly from the suppression to $45 \pm 14 \%$ eIPSC that we observed in control conditions (data not shown; $n=5$ ). Thus, evidently, neither the $\mathrm{mAChR}$ nor the mGluR pathways require intracellular $\mathrm{Ca}^{2+}$ to release endocannabinoids persistently.

To determine whether the effects of mAChR activation on endocannabinoid release may be physiologically relevant, we asked whether ambient ACh can contribute to endocannabinoid release by applying eserine, an ACh esterase inhibitor. Bath application of $2 \mu \mathrm{M}$ eserine enhanced DSI and reduced eIPSC amplitude, and the effects were maximal at 10-15 min of treatment (Fig. 7A). Reversal of the eserine effects by $1 \mu \mathrm{M}$ atropine indicated that the effects were mediated by mAChR. The mimicry of CCh effects by eserine itself shows that a small amount of ACh is constitutively released into extracellular space. $\Delta$ DSI induced by $2 \mu \mathrm{M}$ eserine was $23 \pm 4 \%(n=5 ; p<0.01$; paired $t$ test after repeated measures ANOVA) (Fig. $7 B$ ). The amplitude of eIPSC was significantly reduced by eserine to $85 \pm 3 \%$ of control $(p<$ 0.05; paired $t$ test after repeated measures ANOVA), and this was completely reversed by $1 \mu \mathrm{M}$ atropine $[\Delta \mathrm{DSI}=-1 \pm 3 \%(p>$ $0.1)$, and eIPSC $=100 \pm 3 \%$ of control $(p>0.1)]$. The effects of eserine were not secondary to changes in $\mathrm{Ca}^{2+}$ current because
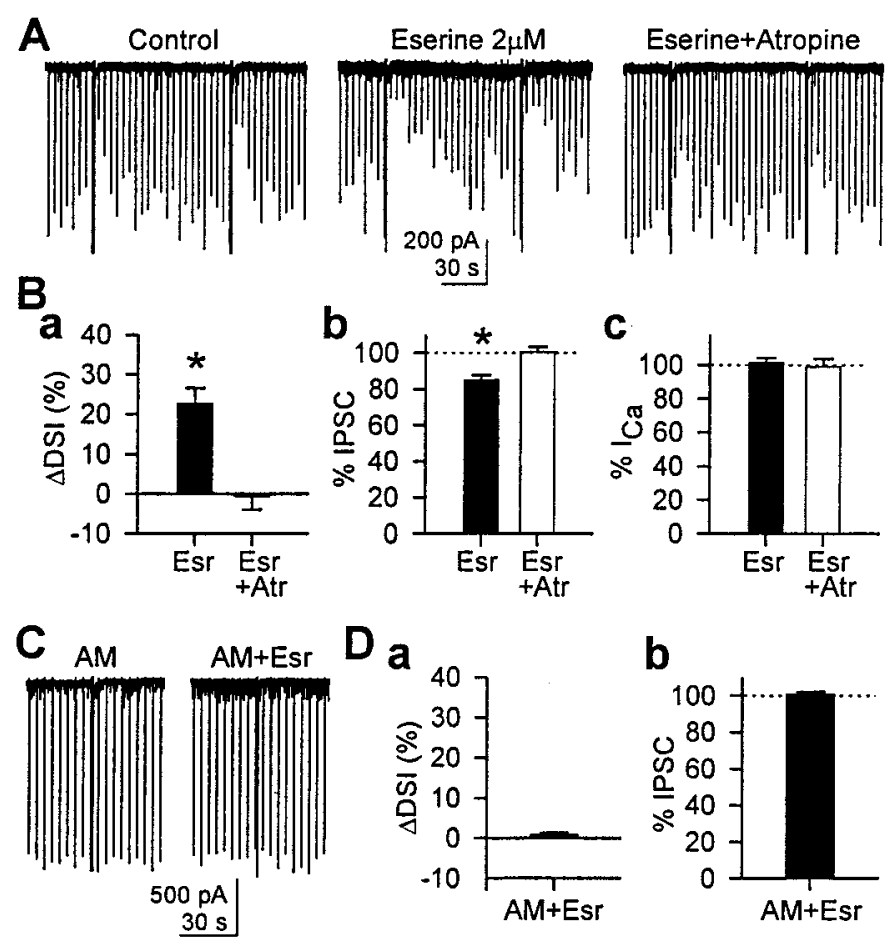

Figure 7. Eserine, the ACh esterase inhibitor, enhanced DSI. A, Sample traces showing that eserine $(2 \mu \mathrm{M})$ enhanced DSI and reduced eIPSC. Both effects were reversed by $1 \mu \mathrm{M}$ atropine. $B$, Group data ( $n=5$ cells) for the effects of eserine and atropine. $a$, DSI was significantly increased $(\Delta \mathrm{DSI}=23 \pm 4 \%)$ by eserine $\left({ }^{*} p<0.01\right.$; paired $t$ test after repeated measures ANOVA). Filled bar, Eserine; open bar, eserine and atropine. $b$, eIPSC amplitude was significantly reduced by eserine to $85 \pm 3 \%$ of control $\left({ }^{*} p<0.05\right.$; paired $t$ test after repeated measures ANOVA). $c$, Peak $\mathrm{Ca}^{2+}$ current, however, was not affected by $2 \mu \mathrm{M}$ eserine $(p>0.1$; repeated measures ANOVA). $C$, AM251 (4 $\mu \mathrm{M})$ abolished the effects of eserine, indicating that the effects of eserine were mediated via CB1R. $D$, Group data ( $n=5$ cells) showing that AM251 blocked the enhancement of DSI $(a)(p>0.1$; paired $t$ test $)$ and reduction of eIPSC amplitudes $(b)$ $(p>0.1$; paired $t$ test) caused by eserine.

eserine did not affect $\mathrm{Ca}^{2+}$ current $(p>0.1$; repeated measures ANOVA) (Fig. $7 B$ ). Pretreatment of slices with AM251 (4 $\mu \mathrm{M})$ abolished the effects of eserine (Fig. $7 C$ ), showing that they were mediated by endocannabinoids. The absence of DSI in the control condition $(-1 \pm 1 \% ; n=5)$ showed that AM251 was effective. With AM251, $\Delta$ DSI induced by $2 \mu \mathrm{M}$ eserine was $1 \pm$ $1 \%(n=5 ; p>0.1$; paired $t$ test $)$, and eIPSC amplitude was $101 \pm$ $2 \%$ of control ( $p>0.1$; paired $t$ test) (Fig. $7 D)$. These results indicate that ambient levels of physiological ACh may be sufficient to induce endocannabinoid release

\section{DISCUSSION}

This is the first study showing that $\mathrm{mAChR}$ activation enhances the release of endocannabinoids. The enhancement appeared in two forms. Low levels of mAChR activation increased the transient release of endocannabinoids that we record as DSI. At higher levels, mAChR activation directly induced the release of endocannabinoids that suppress baseline eIPSCs outside of the DSI period. Endocannabinoid release induced by high concentrations of $\mathrm{CCh}$ persisted for as long as the agonist was applied. The enhancement of DSI was fully blocked by an antagonist of CB1R and was absent in $\mathrm{CB} 1 \mathrm{R}^{-1-}$ mice, and we conclude that at low concentrations $(\leq 0.5 \mu \mathrm{M})$, CCh only affected eIPSCs by enhancing the transient release process. The persistent effect was prom- 
inent when $\mathrm{CCh}$ levels were $\geq 1 \mu \mathrm{M}$. This was also blocked by CB1R antagonist and absent in $\mathrm{CB} 1 \mathrm{R}^{-1-}$ mice but was contaminated by a CB1R-independent effect when $\mathrm{CCh}$ concentrations were $>5 \mu \mathrm{M}$. Although, in principle, enhancement of transient endocannabinoid release could be mediated by an increase in $\mathrm{Ca}^{2+}$ current, or more generally by an increase in $\left[\mathrm{Ca}^{2+}\right]_{\mathrm{i}}$, we observed neither. Enhancement of DSI via mGluR activation is also not associated with an increase in $\left[\mathrm{Ca}^{2+}\right]_{\mathrm{i}}(\mathrm{Ohno}-\mathrm{Shosaku}$ et al., 2002). Application of the AChE inhibitor eserine mimicked all the effects of $\mathrm{CCh}$. Showing that increases in endogenous levels of ACh can induce persistent endocannabinoid release implies that such release may be physiologically relevant.

The mGluR and mAChR effects are initiated independently, because antagonists of one receptor do not affect responses mediated by the other. mGluR and mAChR effects on endocannabinoid release do co-occlude, as expected if they share common intracellular signaling systems. Nevertheless, despite numerous similarities, the mGluR and mAChR effects on endocannabinoid release are not identical. Although maximal activation of mGluRs can suppress eIPSCs to the extent that DSI is almost completely occluded, maximal activation of mAChRs causes less occlusion, and in fact, pronounced DSI is often present in high CCh concentrations. High concentrations of ACPD suppress eIPSCs an average of $67 \%$, and this is entirely mediated by endocannabinoids (Varma et al., 2001). In comparison, high concentrations of CCh $(25 \mu \mathrm{M})$ suppress eIPSCs an average of $71 \%$, but only approximately half of this was mediated by endocannabinoids (Fig. 3D). Most intriguingly, high ACPD is unable to suppress eIPSCs, or further occlude DSI, in the presence of a high concentration of CCh. The existence of DSI in the presence of high CCh clearly implies that endocannabinoids can still be released by the transient, $\mathrm{Ca}^{2+}$-dependent pathway. mAChRs seem to activate the persistent release pathway with only approximately half the efficiency of mGluRs, and high concentrations of CCh prevent full activation of persistent release. Working out the details of the intracellular regulation of endocannabinoid release will clearly be an important task for the future.

Our data suggest that distinct biochemical pathways are involved in the two forms of endocannabinoid release. The persistent release of endocannabinoids either by mAChR (Fig. 6) or by mGluR activation (Maejima et al., 2001; Ohno-Shosaku et al., 2002) is clearly G-protein dependent. We found that persistent, mAChR-mediated endocannabinoid release could not be prevented by loading the cells with BAPTA ( $35 \mathrm{~mm})$, a very high concentration that is fully effective in blocking $\mathrm{Ca}^{2+}$-dependent processes in these cells. This agrees with findings on the persistent, mGluR-mediated release (Maejima et al., 2001). We therefore conclude that the persistent release pathway is not $\mathrm{Ca}^{2+}$ dependent. Because DSI was abolished by 35 mm BAPTA, we are unable to say whether the enhancement of transient endocannabinoid release is $\mathrm{Ca}^{2+}$ dependent. We had thought that this enhancement might be caused by an increase in the $\mathrm{Ca}^{2+}$ signal associated with DSI, but neither voltage-dependent $\mathrm{Ca}^{2+}$ currents nor $\left[\mathrm{Ca}^{2+}\right]_{\mathrm{i}}$ was increased during enhancement of DSI. The enhancement process itself could still be $\mathrm{Ca}^{2+}$ dependent; for example, it might be initiated by $\mathrm{mAChR}$ activation only when $\left[\mathrm{Ca}^{2+}\right]_{\mathrm{i}}$ has been elevated by the $\mathrm{Ca}^{2+}$ influx that initiates DSI.

Despite several similarities between our work and previous work, there are some differences. It has been reported that GTP $\gamma \mathrm{S}$ blocks mGluR-induced endocannabinoid release in cerebellar Purkinje cells (Maejima et al., 2001), whereas we find that GTP $\gamma \mathrm{S}$ strongly activates $\mathrm{mAChR}$-induced endocannabinoid re- lease in hippocampal CA1 cells (Fig. 6). The differences in cell or receptor types may be responsible, although it is not clear whether persistent induction of endocannabinoid release has been ruled out in the cerebellum. $\mathrm{GDP}_{\beta} \mathrm{S}$ reduced, but did not fully block, DSI in cultured hippocampal cells (Ohno-Shosaku et al., 2002), and DSI was still enhanced by mGluR agonists, although to a lesser extent than in the control condition. In our hands, however, $\mathrm{GDP}_{\beta} \mathrm{S}$ did not inhibit DSI and may have enhanced it. A possible explanation is that $\mathrm{GDP}_{\beta} \mathrm{S}$ can be converted in cells to $\mathrm{GTP}_{\beta} \mathrm{S}$, an activator of G-proteins, via the enzyme nucleoside diphosphate kinase (Eckstein et al., 1979; Paris and Pouyssegur, 1990; Piacentini and Niroomand, 1996). If this effect occurs more readily in adult cells in slices than in the cultured cells, then it could account for the different results obtained with $\mathrm{GDP}_{\beta} \mathrm{S}$.

Our findings are relevant to the issue of "spread" of endocannabinoids from one cell to another. Because GTP $\gamma \mathrm{S}$ induced endocannabinoid release, the failure of CCh to decrease eIPSCs further might have been caused by saturation of CB1R by endocannabinoid that was released by GTP $\gamma \mathrm{S}$. In that case, we would not detect the additional release induced by $\mathrm{CCh}$. However, this possibility can be excluded because WIN 55212-2 remained capable of depressing eIPSCs in GTP $\gamma \mathrm{S}$-loaded cells; thus, the CB1Rs on presynaptic terminals cannot have been saturated. A more likely explanation for the absence of CCh effects in GTP $\gamma \mathrm{S}$ loaded cells is that both GTP $\gamma \mathrm{S}$ and $\mathrm{CCh}$ cause a persistent release of endocannabinoids by activating a common G-proteindependent pathway. Previous activation of this pathway by GTP $\gamma \mathrm{S}$ would occlude the ability of $\mathrm{CCh}$ to release more endocannabinoids from that cell. However, nearby cells were not filled with GTP $\gamma \mathrm{S}$, and if endocannabinoids from these cells could diff use to the interneuronal synapses on the GTP $\gamma \mathrm{S}$-loaded cell, bath-applied $\mathrm{CCh}$ would have reduced the eIPSC amplitude. We conclude that failure of $\mathrm{CCh}$ to decrease eIPSCs recorded in GTP $\gamma \mathrm{S}$-loaded cells means that spillover of cannabinoid from nearby cells is unlikely. This agrees with work from the cerebellum (Maejima et al., 2001) and striatum (Gerdeman et al., 2002) that suggests that endocannabinoids do not normally spread from one cell to another, but is at odds with the finding of Wilson and Nicoll (2001) that endocannabinoids released from one cell can act on other cells within a radius of $\leq 20 \mu \mathrm{m}$. The reason for the discrepancy is not known, although it is possible that the release of endocannabinoids from cells stimulated under whole-cell voltage-clamp conditions (Wilson and Nicoll, 2001) is more pronounced than that from intact cells. Pitler and Alger (1994) and Morishita and Alger (2001) saw no evidence for spread of DSI from neighboring cells in most experiments in which the population of intact neighboring cells was stimulated antidromically. In any case, all of these studies agree that retrograde signaling mediated by endocannabinoids is a very localized process.

To date, four of the five mAChR subtypes (M1-M5) have been identified in the hippocampus (Levey et al., 1995). They can be divided into two families, with the odd-numbered members being coupled to phospholipase $\mathrm{C}$ through $\mathrm{G}_{\mathrm{q}}$ and the even-numbered members being coupled to adenylate cyclase through $\mathrm{G}_{\mathrm{i}} / \mathrm{G}_{\mathrm{o}}$ (Caulfield, 1993; Caulfield and Birdsall, 1998). Group I mGluRs, in particular mGluR5 (Morishita et al., 1998; Morishita and Alger, 1999), are effective in mimicking and occluding DSI and do so by releasing endocannabinoids (Varma et al., 2001; OhnoShosaku et al., 2002; our unpublished observations). In the cerebellum, mGluR1 activation releases endocannabinoids (Maejima et al., 2001). The similarity between this previous work and 
our present results strongly suggests that M1, M3, or, conceivably, M5 will be found to mediate CCh-induced endocannabinoid release. Interestingly, the M1 subtype drives population $\gamma$ rhythms in the hippocampus (Fisahn et al., 2002), and activation of CB1Rs can affect rhythmic firing behavior as well (Hajos et al., 2000). We propose that some of the mAChR effects on rhythmic firing behavior are mediated by CB1Rs.

These results may contribute to the reconciliation of contradictory published data. We reported that mGluR antagonists could often reduce DSI (Morishita et al., 1998; Morishita and Alger, 1999; Varma et al., 2001), but other reports did not replicate this observation (Ohno-Shosaku et al., 2001; Wilson and Nicoll, 2001). However, we had studied DSI of eIPSCs in the absence of muscarinic agonists, whereas in other experiments (Wilson and Nicoll, 2001), high concentrations of CCh were used to enhance sIPSC activity so that DSI of sIPSCs could be studied. Therefore, our demonstration that high $\mathrm{CCh}$ can obscure the effects of ACPD on eIPSCs (Fig. 5) can account in part for the discrepant observations, in addition to the likelihood that variations in ambient levels of glutamate play a role (Varma et al., 2001).

Activation of nicotinic AChRs in conjunction with NMDA receptor activation increases the levels of endocannabinoids synthesized in cultured neocortical cells (Stella and Piomelli, 2001), and activation of dopamine D2 receptors increases endocannabinoid synthesis and release in the striatum (Giuffrida et al., 1999). The present work, together with the recent discoveries that mGluR activation enhances endocannabinoid release, greatly expands the scope of these systems. Endocannabinoids must now be suspected to be involved in a wider variety of neuronal activities than thought previously, and conversely, understanding the workings of the conventional transmitter systems will not be possible without a full appreciation of their interactions with the endocannabinoids.

\section{REFERENCES}

Adams PR, Brown DA, Constanti A (1982) Pharmacological inhibition of the M-current. J Physiol (Lond) 332:223-262.

Alger BE, Pitler TA (1995) Retrograde signaling at $\mathrm{GABA}_{\mathrm{A}}$-receptor synapses in the mammalian CNS. Trends Neurosci 18:333-340.

Ameri A (1999) The effects of cannabinoids on the brain. Prog Neurobiol 58:315-348.

Andrade R, Malenka RC, Nicoll RA (1986) A G protein couples serotonin and $\mathrm{GABA}_{\mathrm{B}}$ receptors to the same channels in hippocampus. Science 234:1261-1265.

Beech DJ, Bernheim L, Mathie A, Hille B (1991) Intracellular $\mathrm{Ca}^{2+}$ buffers disrupt muscarinic suppression of $\mathrm{Ca}^{2+}$ current and $\mathrm{M}$ current in rat sympathetic neurons. Proc Natl Acad Sci USA 88:652-656.

Behrends JC, ten Bruggencate G (1993) Cholinergic modulation of synaptic inhibition in the guinea pig hippocampus in vitro: excitation of GABAergic interneurons and inhibition of GABA-release. J Neurophysiol 69:626-629.

Blanton MG, Lo Turco JJ, Kriegstein AR (1989) Whole cell recording from neurons in slices of reptilian and mammalian cerebral cortex. J Neurosci Methods 30:203-210.

Bouaboula M, Perrachon S, Milligan L, Canat X, Rinaldi-Carmona M, Portier M, Barth F, Calandra B, Pecceu F, Lupker J, Maffrand J-P, Le Fur G, Casellas P (1997) A selective inverse agonist for central cannabinoid receptor inhibits mitogen-activated protein kinase activation stimulated by insulin or insulin-like growth factor 1 . J Biol Chem 54:1064-1072.

Buzsaki G (2002) Theta oscillations in the hippocampus. Neuron $33: 325-340$.

Calignano A, La Rana G, Giuffrida A, Piomelli D (1998) Control of pain initiation by endogenous cannabinoids. Nature 394:277-281.

Carlson G, Wang Y, Alger BE (2002) Endocannabinoids facilitate the induction of LTP in the hippocampus. Nat Neurosci 5:723-724.

Caulfield MP (1993) Muscarinic receptors-characterization, coupling and function. Pharmacol Ther 58:319-379.

Caulfield MP, Birdsall NJM (1998) International Union of Pharmacolgy. XVII. Classification of muscarinic acetylcholine receptors. Pharmacol Rev 50:279-290.

Cole AE, Nicoll RA (1984) Characterization of a slow cholinergic post- synaptic potential recorded in vitro from rat hippocampal pyramidal cells. J Physiol (Lond) 352:173-188.

Di Marzo V, Melck D, Bisogno T, De Petrocellis L (1998) Endocannabinoids: endogenous cannabinoid receptor ligands with neuromodulatory action. Trends Neurosci 21:521-528.

Dolphin AC (1995) Voltage-dependent calcium channels and their modulation by neurotransmitters and G proteins. Exp Physiol 80:1-36.

Eckstein F, Cassel D, Levkovitz H, Lowe M, Selinger Z (1979) Guanosine 5'-O-(2-thiodiphosphate), an inhibitor of adenylate cyclase stimulation by guanine nucleotides and fluoride ions. J Biol Chem 254:9829-9834.

Fisahn A, Pike FG, Buhl EH, Paulsen O (1998) Cholinergic induction of network oscillations at $40 \mathrm{~Hz}$ in the hippocampus in vitro. Nature 394:186-189.

Fisahn A, Yamada M, Duttaroy A, Gan J-W, Deng C-X, McBain CJ, Wess J (2002) Muscarinic induction of hippocampal gamma oscillations requires coupling of the M1 receptor to two mixed cation currents. Neuron 33:615-624.

Fischer Y, Gahwiler BH, Thompson SM (1999) Activation of intrinsic hippocampal theta oscillations by acetylcholine in rat septohippocampal cocultures. J Physiol (Lond) 519:405-413.

Fitzjohn SM, Bortolotto ZA, Palmer MJ, Doherty AJ, Ornstein PL, Schoepp DD, Kingston AE, Lodge D, Collingridge GL (1998) The potent mGlu receptor antagonist LY341495 identifies roles for both cloned and novel mGlu receptors in hippocampal synaptic plasticity. Neuropharmacology 37:1445-1458.

Fraser DD, MacVicar BA (1996) Cholinergic-dependent plateau potential in hippocampal CA1 pyramidal neurons. J Neurosci 16:4113-4128.

Gerdeman GL, Ronesi J, Lovinger DM (2002) Postsynaptic endocannabinoid release is critical to long-term depression in the striatum. Nat Neurosci 5:446-451

Giuffrida A, Parsons LH, Kerr TM, Rodriguez de Fonseca F, Navarro M, Piomelli D (1999) Dopamine activation of endogenous cannabinoid signaling in dorsal striatum. Nat Neurosci 2:358-363.

Guérineau NC, Bossu J-L, Gahwiler BH, Gerber U (1995) Activation of a nonselective cationic conductance by metabotropic glutamatergic and muscarinic agonists in CA3 pyramidal neurons of the rat hippocampus. J Neurosci 15:4395-4407.

Hajos N, Katona I, Naiem SS, Mackie K, Ledent C, Mody I, Freund TF (2000) Cannabinoids inhibit hippocampal GABAergic transmission and network oscillations. Eur J Neurosci 12:3239-3249.

Halliwell JV, Adams PR (1982) Voltage-clamp analysis of muscarinic excitation in hippocampal neurons. Brain Res 250:71-92.

Hoffman AF, Lupica CR (2000) Mechanisms of cannabinoid inhibition of $\mathrm{GABA}_{\mathrm{A}}$ synaptic transmission in the hippocampus. J Neurosci 20:2470-2479.

Howe AR, Surmeier DJ (1995) Muscarinic receptors modulate N-, P-, and L-type $\mathrm{Ca}^{2+}$ currents in rat striatal neurons through parallel pathways. J Neurosci 15:458-469.

Katona I, Sperlagh B, Sik A, Kafalvi A, Vizi ES, Mackie K, Freund TF (1999) Presynaptically located CB1 cannabinoid receptors regulate GABA release from axon terminals of specific hippocampal interneurons. J Neurosci 19:4544-4558.

Ledent C, Valverde O, Cossu G, Petitet F, Aubert J-F, Beslot F, Bohme GA, Imperato A, Pedrazzini T, Roques BP, Vassart G, Fratta W, Parmentier M (1999) Unresponsiveness to cannabinoids and reduced addictive effects of opiates in CB1 receptor knockout mice. Science 283:401-404.

Lenz RA, Alger BE (1999) Calcium dependence of depolarizationinduced suppression of inhibition in rat hippocampal CA1 pyramidal neurons. J Physiol (Lond) 521:147-157.

Levey AI, Edmunds SM, Koliatsos V, Wiley RG, Heilman CJ (1995) Expression of $\mathrm{m} 1-\mathrm{m} 4$ muscarinic acetylcholine receptor proteins in rat hippocampus and regulation by cholinergic innervation. J Neurosci 15:4077-4092.

Llano I, Leresche N, Marty A (1991) Calcium entry increases the sensitivity of cerebellar Purkinje cells to applied GABA and decreases inhibitory synaptic currents. Neuron 6:565-574.

Madison DV, Lancaster B, Nicoll RA (1987) Voltage clamp analysis of cholinergic action in the hippocampus. J Neurosci 7:733-741.

Maejima T, Hasimoto K, Yoshida T, Aiba A, Kano M (2001) Presynaptic inhibition caused by retrograde signal from metabotropic glutamate to cannabinoid receptors. Neuron 31:463-475.

Martin LA, Alger BE (1999) Muscarinic facilitation of the occurrence of depolarization-induced suppression of inhibition in rat hippocampus. Neuroscience 92:61-71.

Martin LA, Wei D-S, Alger BE (2001) Heterogeneous susceptibility of $\mathrm{GABA}_{\mathrm{A}}$ receptor-mediated IPSCs to depolarization-induced suppression of inhibition in rat hippocampus. J Physiol (Lond) 532:685-700.

Morishita W, Alger BE (1999) Evidence for endogenous excitatory amino acids as mediators in DSI of GABA $_{A}$ ergic transmission in hippocampal CA1. J Neurophysiol 82:2556-2564.

Morishita W, Alger BE (2001) Direct depolarization and antidromic action potentials transiently suppress dendritic IPSPs in hippocampal CA1 pyramidal cells. J Neurophysiol 85:480-484. 
Morishita W, Kirov SA, Alger BE (1998) Evidence for metabotropic glutamate receptor activation in the induction of depolarizationinduced suppression of inhibition in hippocampal CA1. J Neurosci 18:4870-4882.

Nicoll RA, Alger BE (1981) A simple chamber for recording from submerged brain slices. J Neurosci Methods 4:153-156.

Ohno-Shosaku T, Sawada S, Yamamoto C (1998) Properties of depolarization-induced suppression of inhibitory transmission in cultured rat hippocampal neurons. Pflügers Arch 435:273-279.

Ohno-Shosaku T, Maejima T, Kano M (2001) Endogenous cannabinoids mediate retrograde signals from depolarized postsynaptic neurons to presynaptic terminals. Neuron 29:729-738.

Ohno-Shosaku T, Shosaku J, Tsubokawa H, Kano M (2002) Cooperative endocannabinoid production by neuronal depolarization and group. I metabotropic glutamate receptor activation. Eur J Neurosci 15:953-961.

Pan X, Ikeda SR, Lewis DL (1998) SR 141716A acts as an inverse agonist to increase neuronal voltage-dependent $\mathrm{Ca}^{2+}$ currents by reversal of tonic CB1 cannabinoid receptor activity. Mol Pharmacol 54:1064-1072.

Panikashvili D, Simeondiou C, Ben-Shabat S, Hanus L, Breuer A, Mechoulam R, Shomani E (2002) An endogenous cannabinoid (2AG) is neuroprotective after brain injury. Nature 413:527-531.

Paris S, Pouyssegur J (1990) Guanosine 5'-O-(3-thiotriphosphate) and guanosine $5^{\prime}-\mathrm{O}-(2$-thiodiphosphate) activate $\mathrm{G}$ proteins and potentiate fibroblast growth factor-induced DNA synthesis in hamster fibroblasts. J Biol Chem 265:11567-11575.

Piacentini L, Niroomand F (1996) Phosphotransfer reactions as a means of $\mathrm{G}$ protein activation. Mol Cell Biochem 157:59-63.

Piomelli D, Giuffrida A, Calignano A, Rodriguez de Fonseca F (2000) The endocannabinoid system as a target for therapeutic drugs. Trends Pharmacol Sci 21:218-224
Pitler TA, Alger BE (1992a) Cholinergic excitation of GABAergic interneurons in the rat hippocampal slice. J Physiol (Lond) 450:127-142.

Pitler TA, Alger BE (1992b) Postsynaptic spike firing reduces synaptic $\mathrm{GABA}_{\mathrm{A}}$ responses in hippocampal pyramidal cells. J Neurosci 12:4122-4132.

Pitler TA, Alger BE (1994) Depolarization-induced suppression of GABAergic inhibition in rat hippocampal pyramidal cells: G protein involvement in a presynaptic mechanism. Neuron 13:1447-1455.

Shapiro MS, Loose MD, Hamilton SE, Nathanson NM, Gomeza J, Wess J, Hille B (1999) Assignment of muscarinic receptor subtypes mediating $\mathrm{G}$-protein modulation of $\mathrm{Ca}^{2+}$ channels by using knockout mice. Proc Natl Acad Sci USA 96:10899-10904.

Stella N, Piomelli D (2001) Receptor-dependent formation of endogenous cannabinoids in cortical neurons. Eur J Pharmacol 425:189-196.

Tsou K, Brown S, Sanudo-Pena MC, Mackie K, Walker JM (1998) Immunohistochemical distribution of cannabinoid CB1 receptors in the rat central nervous system. Neuroscience 83:393-411.

van der Stelt M, Veldhuis WB, van Haaften GW, Fezza F, Bisogno T, Bar PR, Veldink GA, Vliegenthart JFG, Di Marzo V, Nicolay K (2001) Exogenous anandamide protects rat brain against acute neuronal injury in vivo. J Neurosci 21:8765-8771.

Varma N, Carlson GC, Ledent C, Alger BE (2001) Metabotropic glutamate receptors drive the endocannabinoid system in hippocampus. J Neurosci 21:RC188(1-5).

Wilson RI, Nicoll RA (2001) Endogenous cannabinoids mediate retrograde signalling at hippocampal synapses. Nature 410:588-592.

Wilson RI, Kunos G, Nicoll RA (2001) Presynaptic specificity of endocannabinoid signaling in the hippocampus. Neuron 31:453-462.

Yan Z, Surmeier DJ (1996) Muscarinic $(\mathrm{m} 2 / \mathrm{m} 4)$ receptors reduce Nand $\mathrm{P}$-type $\mathrm{Ca}^{2+}$ currents in rat neostriatal cholinergic interneurons through a fast, membrane-delimited, G-protein pathway. J Neurosci 16:2592-2604. 